\title{
Forandrer Facebook partiernes forhold til vælgerne?
}

\author{
Lars Duvander Højholt \& Karina Kosiara-Pedersen
}

hhv. stud.scient.pol. og lektor ved Institut for Statskundskab, Københavns Universitet

Facebook har et potentiale til at skabe politisk dialog og nye relationer til vælgerne. Udnytter danske folketingsmedlemmer denne mulig for at forandre den politiske debat og vælgernes tilknytning? Kun en fjerdedel af de danske folketingsmedlemmer har en Facebook-side, der er velegnet til kommunikation med vælgerne. Der finder interaktion sted på partiledernes sider, der er de mest populære, men mobiliseringen og den brede aktivitet sker primært blandt partiledernes venner og fans. Men hvis partilederne vil, kan de udnytte Facebooks potentiale til at skabe politisk dialog og nye relationer til vælgerne.

Facebook er på kort tid blomstret op og blevet danskernes foretrukne virtuelle forsamlingshus. Det populære netværk er i sin essens et udtryk for internettets unikke potentiale til at bygge forbindelser på tværs af geografiske, kulturelle og sociale skel. Det er her vi mødes med venner og bekendte og knytter nye forbindelser, ikke blot perifære sociale forbindelser, men også relationer til produkter, organisationer, musikere og - i denne sammenhæng særligt interessant - partier, politiske organisationer og politikere.

Facebook og andre sociale mediers enorme popularitet har kastet store forventninger af sig. Blandt de mest optimistiske er forventningen om, at internettets modning og de sociale mediers opblomstring vil føre til en digital revolution, der vil ændre vores måde at samarbejde på og helt grundlæggende give anledning til demokratisk fornyelse via direkte interaktion med politikerne i parlamentet. At internettet og de sociale medier kan åbne op for en bredere inddragelse og et mere dialogbaseret demokrati (Norris 2001).

Visionerne om de sociale mediers deliberative og deltagerdemokratiske potentiale har en række fællestræk med de forventninger, der knytter sig til relationship marketing og dets potentiale til at revitalisere politik. De normative forventninger til relationship marketing er, at det dialogbaserede forhold mellem politiker og vælgere mindsker fremmedgørelsen i forhold til politik og politikere, øger borgernes involvering i udformningen af politik, og skaber en mere oplyst vælgerskare (Bannon 2005).

Relationship marketing kan komme til udtryk på mange måder, men feltet går utvivlsomt hånd $\mathrm{i}$ hånd med den digitale udvikling og har i hvert fald fået styrket sin position i forlængelse heraf. Sociale medier giver nemlig mulighed for, at politikerne ,gennem social interaktion på webstedet kan få direkte input fra vælgere“ (Klastrup 2008, 37).

Spørgsmålet er, om de danske partier gør brug af de nye metoder. I hvilket omfang bruger de Facebook til at indgå i nye relationer med vælgerne? I det følgende afsnit præsenteres relationship marketing kort. Efterfølgende præsenteres metode, analyseramme og data. Analysen viser først, i hvilket omfang partierne er til stede på Facebook, dernæst hvad der karakteriserer deres relation til vælgerne på Facebook. Afslutningsvist konkluderes, at selvom partier og partiledere er på Facebook, der gi- 
ver gode muligheder for relationship marketing, er det begrænset, hvor meget dialog og debat, partierne skaber derigennem.

\section{Relationship marketing i politiske partier}

Det overordnede og oprindelige begreb 'marketing', som denne analyses teoriapparat trækker på, har sin oprindelse i mikroøkonomisk tankegang og sin raison d'être i bestræbelsen på at øge salget af et givent produkt.

Formålet med at satse på marketing er i en økonomisk logik at få flere til at købe ens produkt, og fokus ligger dermed på transaktionen mellem køber og sælger. Den konkrete udførelse er i den økonomiske teori som oftest blevet konceptualiseret og foreskrevet i marketing mix'ets 4 p'er: produkt, placering, pris og promovering. Det er sælgeren, som er den aktive part, der tilpasser de fire kerneelementer i marketingsmikset for at overbevise den ellers passive køber om at foretage et køb (Grönroos 1994, 8).

Den teoretiske forståelse og praktiske tilgang er sidenhen overført fra industrielle produkter til services, organisationer og ideer (Kotler \& Levy 1969; Kotler 1972; Grönroos 1994), og i forlængelse heraf til den politiske sfære i form af politisk marketing (Lees-Marshment 2001a; Lees-Marshment 2001b; Henneberg 2002). Mens erhvervslivets marketingchefer skal sælge produkter og services, skal den politiske marketing sælge budskaber, image og værdier. Metoderne til at gøre det er, ifølge teorien, imidlertid grundlæggende de samme.

Men produkter og politik er netop ikke altid det samme. Derfor er perspektivet blevet kritiseret for at være en kortsigtet strategi, der har klare og udtalte begrænsninger i forhold til forstålsen af moderne politik - både hvad angår det politiske produkt og forståelsen af den moderne vælger (Henneberg \& O’Shaugnessy 2009, 8). Det er netop kritikken af det kortsigtede perspektiv, der har ledt frem til det teoretiske paradigmeskifte mod relationship marketing. Grönroos definerer det således:

\section{„Relationship marketing is to establish, maintain, enhance relationships with customers and other partners, at a profit, so that the objectives of the parties involved are met. This is achieved by a mutual exchange and fulfillment of promises. Such relationships are usually but not necessarily always longterm." (1994, 9).}

Modsat økonomisk eller traditionel politisk marketing er det centrale i relationship marketing opbygningen af relationer og den gensidige opfyldelse af løfter. Relationship marketing er, med sit fokus på relationen mellem producent og forbruger og det fælles udbytte af denne relation, bedre tilpasset til den politiske sfære og det politiske 'produkt'. Det politiske produkt består af mere end bare politik, ideologi og visioner, men også partiets image og symboler samt politiske ledere, ansatte og kandidater (Lloyd 2005). Politikernes fremtoning, troværdighed og image har således vist sig at have betydning for, hvor vi sætter vores kryds (Strömbäck 2007, 56; jvf. Jackson 2006, 157).

De klassiske bånd mellem partier og klasse er blevet afløst af nye relationer mellem partier og vælgere. Relationship marketing er én af de måder, hvorpå partier kan skabe nye forbindelser til vælgerne.

Forholdet til borgerne er et centralt aktiv for partier, politikere, organisationer m.m. (Bannon 2005, 73). Forholdet baseres på tillid og gensidighed (Grönroos 1994, 9), og i litteraturen foreskrives en række faktorer, der kendetegner relationship marketing og er afgørende for at opbygge, vedligeholde og udbygge disse relationer.

Udøvelsen af relationship marketing er modsat politisk marketing ikke parkeret $i$ en selvstændig enhed i partiorganisationen, men er et tankesæt, der er implementeret bredt, så alle deltager i markedsføring og opbygning af relationer; relationship marketing er integreret i organisationen (Grönroos 1994, 10).

Relationship marketing indebærer derudover et strategisk skifte i tidsperspektivet fra kortsigtet transaktionsfokus til fokus på langsigtede relationer, der vedligeholdes og udbygges i tiden mellem „købsituationer", dvs. valgdagene (Grönroos 1994; Henneberg \& O'Shaugnessy 2009; Bannon 2005; Jackson 2006).

Centralt for forholdet står interaktion og dialog mellem parterne; og det skal have værdi for begge parter (Henneberg \& O'Shaugnessy 2009). Derfor skifter fokus fra manipulation af budskaber til dialog og samarbejde om politik. Brugerne bliver ideelt set mere og mere involveret $\mathrm{i}$ udvekslingsprocessen og i værdiskabelsen gennem samarbejde (Henneberg \& O'Shaugnessy 2009, 9). I en relationship marketing strategi er det muligheden for at blive hørt, for at bidrage til debat og udvikling, dvs. involvering i udviklingen af politik, der udgør værdien for vælgerne. Strategien handler om, hvordan man kan gøre det politiske produkt åbent for involvering og udvidelse (Dermody \& Scullian 2000).

Forholdet kan yderligere stimuleres via eksklusivitet, hvor de der har et nært forhold til politikerne får først og særlig adgang til information. Det er eksemplificeret ved Obamas besked om nominering af sin vice-præsident under valgkampen - en besked der ikke blev lanceret i de nationale medier men til Obamas følgere på twitter. Solidaritet, der opstår herfra, kan være med til at skabe politisk medejerskab (Dermody \& Scullian 2000, 12), og loyaliteten kan være med til at gøre vælgerne til ambassa- 
dører for de politiske budskaber (Scarrow 1996; Bannon 2005; Keller 2001).

Analysen er, bl.a. med inspiration fra Grönroos (1994) og Jackson (2006), opdelt i to hovedtemaer: For det første partiernes implementering af relationship marketing. En forudsætning for den eksterne marketingsindsats succes afhænger i relationship marketing af, hvorvidt tankegangen er appliceret internt - dvs. at marketingsindsatsen ikke blot parkeres i en særskilt marketingsafdeling, men påtages i mere eller mindre grad af alle i partiet. Og at relationen kontinuerligt skabes og genskabes. For det andet aktivitet. Kernen i relationship marketing og det, der for politisk kampagner, er relationen - eller information og interaktionen mellem politikerne og deres vælgere. Disse to hovedtemaer operationaliseres nedenfor.

\section{Hvordan undersøges relationship marketing i danske partier?}

Interaktion og en stærk relationship marketing strategi kræver et to-vejs kommunikationsmedie med hurtige feedbackmuligheder samt muligheden for at vurdere og respondere på feedback (Henneberg \& O’Shaugnessy 2009). Netop de nyere sociale medier giver mulighed for dette; og specielt Facebook synes skræddersyet dertil.

Facebook er en af de mange digitale platforme, der er opblomstret i de seneste år, og som derfor er en etableret del af partiernes digitale værktøjskasse. Udover Facebook er også medier som Flickr og Twitter er del af arsenalet. Men der er ingen platform, der har en større digital koncentration af danskere end Facebook. Bare i Danmark er der i dag 2,6 millioner brugere af netværket - bredt fordelt på køn og alle aldersgrupper, om end gruppen over 65 år er lidt underrepræsenteret (Facebook 2010). Faktisk ville Facebook med sine 500 mio. brugere være verdens tredje største nation, hvis der var tale om en fælles enhed.

En analyse af partiernes brug af Facebook er relevant, for det første fordi Facebooks centrale valuta er relationer. For det andet er Facebook så udbredt, at alle aldersgrupper, klasser, køn og alle andre former for sociale strata er repræsenteret. Facebook er med sine egenskaber et oplagt medie til at anvende relationship marketing og dermed også til at analysere partier og partilederes forhold til vælgerne online. Facebook er en kritisk case; hvis ikke partier og partiledere udøver relationship marketing her, er det usandsynligt, at de vil gøre det andre steder i det digitale univers.

Undersøgelsen af partiernes brug af relationship marketing via Facebook tager udgangspunkt i netværkets iboende funktionaliteter og de muligheder, der er. Analysen er, som nævnt ovenfor, opdelt i to dele: Implementering og aktivitet.
Først analyseres, i hvilken grad danske partier har implementeret relationship marketing gennem brug af Facebook. Det er relevant at undersøge, hvor udbredt brugen af Facebook er i partiet. Er det kun et par enkelte politikere, der anvender redskabet, eller er det bredt implementeret i partiet, så alle folketingsmedlemmer, både partiledere, ordførere og backbenchers er til stede?

\section{Hvor stor en andel af partiernes folketingsmedlemmer er til stede på Facebook?}

Typisk har de fleste personer en personlig profil, hvor man har accepteret dem, der anmoder om venskab, fordi man kender dem på den ene eller anden måde. Information er her tilgængeligt i det omfang, brugeren er villig til at lade andre se billeder og beskeder. Personlige profiler er derfor som oftest lukkede fora båret af en personlig relation etableret forud for det digitale venskab.

Offentlige personer opretter derimod som oftest en side, hvor al information er offentlig tilgængelig. Sider anvendes ikke kun af enkeltpersoner, men udgør også platformen for organisationer, bevægelser og partier, som ikke må oprette personlige profiler. Sider har derfor mere præg af fankultur og en klar selektion af, hvilke beskeder og billeder, man mener er passende i forhold til sidens karakter. Tidligere blev man netop en del af siden ved at erklære sig fan. I dag får man fuld adgang ved at klikke af ved „synes godt om“, som det hedder i Facebook-terminologi.

Til brug for indeværende undersøgelse anses sider som et valg, der i højere grad muliggør relationship marketing end profiler.

\section{Hvilke andele af partiernes folketingsmedlemmer anven- der profiler og sider?}

Sociale medier og Facebook i særdeleshed forudsætter relationer, idet vælgerne bliver nødt til at „synes godt om“ politikerne eller anmode om „venskab“ for at kunne følge opdateringer og for selv at have muligheden for at deltage. Når en vælger aktivt har søgt relationen, er det langsigtede forhold med andre ord en realitet - indtil vælgeren fravælger det.

Facebook anses for at være bedre til at bevare og udbygge forhold end til at skaffe nye fans. Det skyldes, at vælgernes medlemskaber på Facebook bliver en del af deres egen offentlige profil og identitet og troløsheden blandt vælgere in mente antages det, at det kun er de mest engagerede, der ønsker at skilte med deres politiske overbevisning. 
3. Hvor mange venner/fans har folketingsmedlemmernes Facebook sider/profiler? (absolut antal, ift. antal valgere og ift. antal partimedlemmer)

I anden del af analysen fokuseres på aktiviteten. Selv om de enkelte partier hver har en side på Facebook, er det som oftest partilederen, der er partiernes primære ansigt udadtil. Partilederne har i alle tilfælde også markant flere fans end partiernes egne sider. Det stemmer godt overens med den profilering og opmærksomhed, der er omkring kandidaterne i medierne og teoretiseringen over betydningen af personligt image i litteraturen (Jackson 2006, 157; Pedersen \& Knudsen 2005). For at begrænse datamaterialet fokuseres derfor på partilederne.

Partilederne er på tidspunktet for dataindsamling (se nedenfor): Villy Søvndal, SF; Helle Thorning-Schmidt, Socialdemokraterne (S); Margrethe Vestager, Radikale (RV); Lene Espersen, Konservative (KF); Lars Løkke Rasmussen, Venstre (V); Pia Kjærsgaard, Dansk Folkeparti (DF) og Anders Samuelsen, Liberal Alliance (LA). Da Enhedslisten ikke har nogen officiel partileder, indgår Johanne Schmidt-Nielsen (EL), i sin egenskab af politisk ordfører og det mest profilerede medlem af folketingsgruppen.

Analysen af interaktionen på Facebook tager sit udgangspunkt i „væggen“ - det centrale mødested på Facebook. Det er her, der kommunikeres og interageres. Al aktivitet på Facebook havner på væggen i form af en „wall-post", som alle har mulighed for enten at "like“ eller kommentere på. Ofte har fans mulighed for at skrive indlæg på væggen, som ligeledes er åben for kommentarer og „likes“. Kommentarer ses i denne analyse som en indikator på interaktionsniveauet på siden, mens „likes“ indikerer enighed om politikernes budskaber - den ideologiske homogenitet blandt sidens fans. Det centrale datagrundlag for nedenstånde analyser vil være optælling og analyse af indlæg på væggen.

Hyppigheden af partiledernes indlæg på væggen er en indikator for ønsket om herigennem at skabe et forhold til vælgerne ved at give dem information eller opfordre til debat.

\section{Hvor mange wall-posts er afsendt af partilederen? (absolut antal og ift. antal fans/venner)}

Reaktioner fra fans viser opbakningen til relationen og viljen til at forholde sig til den givne information og indgå i dialog med partilederne. Det er et udtryk for, om vælgerne har lyst til at engagere sig og deltage.

\section{Hvor mange kommentarer har fans til partiledernes wall-} posts, pr. wall-post?

\section{Hvor mange "likes" har fans til partiledernes wall-posts,} pr. wall-post?

Facebook giver ikke kun mulighed for, at partildere kan give fans (eksklusiv) information eller skabe debat om selv-valgte emner. Det giver også mulighed for, at fans starter og skaber debatter - vel at mærke hvis partilederen giver mulighed for dette.

7. Hvor mange wall-posts er afsendt af fans/venner, absolut og ift. antal fans?

\section{Hvor mange kommentarer har fans/venner til wall-posts fra fans/venner pr. post?}

\section{Hvor mange "likes" har fans/venner til wall-posts fra fans/} venner pr. post?

Engagement og deltagelse kan stimuleres med partilederens egen aktivitet og karakteren af aktiviteten. Bruger partilederne primært Facebook til envejskommunikation og lader fans/venner om debatten, eller deltager de i debatten ved at kommentere på egne og andres indlæg?

10. Hvor mange svar giver partilederen på kommentarer til egne wall-posts pr. post?

11. Hvor mange svar giver partilederen til wall-posts fra fans/venner pr. post?

Partiledernes aktivitet på Facebook undersøges for at vise, hvilken karakter interaktionen mellem partileder og fans har. Facebook muliggør personlig kommunikation af en anden karakter end typisk politisk kommunikation. I analysen skelnes mellem tre typer af indlæg:

- Politiske indlag, som kan tage form af ytringer om egen politik, kritik af andres forslag eller opdateringer om aktiviteter. Det er politisk kommunikation; afgørende for dialog og involvering - men ikke unik for Facebook.

- Personlige indlag dækker indlæg uden politisk indhold, men hvor partilederen giver mere af sig selv på det private plan - fødselsdagshilsner og kommentarer om musik eller oplevelser. Billeder vurderes også som personlige, hvis det politiske budskab ikke er det centrale. De personlige indlæg er mere i Facebooks natur og med til at vise, om der er tale om mere personlige relationer, end traditionel kommunikation af politiske budskaber.

- Dialogbaserede indlag dækker over spørgsmål til fans/ venner, beskeder direkte til enkelte eller alle og opfordringer til bestemte handlinger. Dialogbaserede 
indlæg opfordrer direkte til interaktion og er derfor det stærkeste tegn på, at partilederne offensivt søger at involvere deres vælgere og skabe indholdsrige og gensidige relationer.

Nogle wall-posts kan være flere ting på samme tid, men der kodes efter altovervejende vægt. Et eksempel: „Hvad vil du skrive eller tegne på et badge for at udtrykke din holdning til pointsystemet for ægtefæller?"“ Indlægget har et politisk fokus, men er en direkte opfordring til at involvere sig og udtrykke holdninger, og kategoriseres derfor som et dialogbaseret indlag.

\section{Er partiledernes wall-posts primart politiske, personlige eller dialogbaserede?}

For at besvare disse i alt tolv spørgsmål har det været nødvendigt med visse begrænsninger. Optællinger af folketingsmedlemmernes sider/profiler og antal fans/venner er foretaget 10.-12. december 2010.

Eksplorative stikprøver af partiledernes aktivitet på væggen viste, at en måneds opdateringer er tilstrækkeligt til at kunne konkludere på analysens spørgsmål. Perioden er af en tilstrækkelig længde til, at partilederne kan udtrykke sig varieret om både politiske budskaber, personlige ytringer og give deres reaktioner på vigtige begivenheder. November 2010 udgør tidsperioden for indsamling af data.

Fan-initierede indlæg på partiledernes sider er også genstand for analyse, men tidsperioden er pga. det omfangsrige datamateriale reduceret til én uge. Konkret udgør uge 49 (fra mandag d. 29.11.10 til søndag d. 5.12.10) datagrundlaget. Den konkrete uge er udvalgt for at sikre, at kommentarerne ikke domineres af en altoverskyggende sag, men kan kendetegnes som en typisk uge. Det valgte interval er således et par uger efter, at det nye pointsystem for familiesammenføring blev lanceret, og ugen før offentliggørelsen af PISA-resultaterne for danske elevers kompetencer og den efterfølgende lancering af regeringens plan for folkeskolen. Der skete ikke noget særligt i ugen op til den valgte uge, der skulle gøre den atypisk.

I de to næste afsnit analyseres først, hvorvidt danske partier anvender Facebook (spg. 1-3). Dernæst aktiviteten og dermed hvilken karakter interaktionen mellem vælgere og partiledere på Facebook har (spg. 4-12). Afslutningsvist konkluderes.

\section{Implementering af relationship marketing gen- nem Facebook}

Samtlige danske MF'eres tilstedeværelse på Facebook er kortlagt for at give en indikation af, hvorvidt danske partier har implementeret relationship marketing gennem Facebook (Tabel 1).
På den ene side er tilstedeværelsen på Facebook relativt høj, idet to tredjedele af politikerne er på Facebook. På den anden side er det med folketingsmedlemmernes uddannelse, gennemsnitsalder og ikke mindst position i samfundet in mente alligevel overraskende, at andelen ikke er større. Ikke mindst i betragtning af, at der i Danmark er 2,6 mio. profiler på den sociale netværksside.

Tabel 1. Folketingsmedlemmer med Facebook profiler, sider eller ingen af delene, pct. (antal).

\begin{tabular}{|l|c|c|c|}
\hline $\begin{array}{l}\text { Parti } \\
\text { (antal MF'ere i alt) }\end{array}$ & $\begin{array}{c}\text { Andel MF'ere } \\
\text { med side } \\
\text { (antal) }\end{array}$ & $\begin{array}{c}\text { Andel } \\
\text { MF'ere med } \\
\text { profil (antal) }\end{array}$ & $\begin{array}{c}\text { Andel MF'ere } \\
\text { uden side/profil } \\
\text { (antal) }\end{array}$ \\
\hline Venstre (47) & $19(9)$ & $49(23)$ & $32(15)$ \\
\hline Socialdemokraterne (45) & $18(8)$ & $62(28)$ & $20(9)$ \\
\hline Dansk Folkeparti (24) & $8(2)$ & $8(2)$ & $83(20)$ \\
\hline SF (23) & $39(9)$ & $48(11)$ & $13(3)$ \\
\hline Konservative (17) & $53(9)$ & $29(5)$ & $18(3)$ \\
\hline Radikale Venstre (9) & $22(2)$ & $33(3)$ & $44(4)$ \\
\hline Enhedslisten (4) & $25(1)$ & $75(3)$ & $0(0)$ \\
\hline Liberal Alliance (3) & $67(2)$ & $33(1)$ & $0(0)$ \\
\hline Nordiske (4) & $0(0)$ & $25(1)$ & $75(3)$ \\
\hline Løsgængere (3) & $0(0)$ & $33(1)$ & $67(2)$ \\
\hline I alt (179) & $23(42)$ & $44(78)$ & $33(59)$ \\
\hline
\end{tabular}

Note: Hvis MF'er har både en profil og side tæller den, som har flest venner/ fans. Data indsamlet 10.-12. december 2010.

Dansk Folkeparti er mindst repræsenteret og trækker dermed gennemsnittet væsentligt ned. Venstre, landets største parti, har hele 15 MF'ere (32 pct.), der slet ikke er til stede på Facebook. Det kan muligvis skyldes, at Venstre har mange kandidater i befolkningstynde områder i Vestjylland, hvor Facebook ifølge statistikkerne er mindst udbredt. Storbypartiet SF er da også det bedst repræsenterede.

Det er også interessant, at en række af regeringens højtprofilerede ministre som Troels Lund Poulsen, Birthe Rønn Hornbech, Gitte Lillelund Bech, Hans Christian Schmidt og Charlotte Sahl-Madsen slet ikke er tilstede på Facebook.

Af de MF'ere, der er til stede, har 42 (23 pct.) oprettet en side for deres politiske identitet, mens 79 ( 44 pct.) kun er repræsenteret ved deres personlige profiler. Oprettelsen af en side er, som tidligere beskrevet, et mere strategisk træk end bevarelsen af en personlig og for offentligheden lukket profil; relationship marketing via Facebook er kun i begrænset omfang implementeret hele vejen gennem partiernes folketingsgrupper.

Det understreges også af, at det typisk kun er de mest profilerede politikere som partiledere og fremtrædende ordførere, der har sider. Den strategiske brug af Facebook 
er forbeholdt en beskeden del af de politiske partiers mest profilerede politikere.

Selvom det ganske vist er to tredjedele af Folketingsmedlemmerne, der er til stede på Facebook, er det kun en fjerdedel, der bruger det sociale medies funktioner $\mathrm{i}$ forhold til vælgerne generelt. Implementeringen af Facebook som relationship marketings-redskab er begrænset.

Et nærmere kig på de tilstedeværende folketingsmedlemmers antal fans/venner viser, at siderne og ikke mindst profilerne ikke har så bred forankring. De menige MF'ere, som er mest ombejlet på Facebook, er Socialdemokraternes Mette Frederiksen og Christine Antorini med henholdsvis 15.460 og 7.949 fans. Men mange profiler har kun omkring 400 venner og det gennemsnitlige antal fans og venner ligger på 1.978. Det er på den ene side et stykke fra de ca. 20.000 stemmer, et folketingsmandat 'koster'. På den anden side er det kun halvdelen af vælgerne, der stemmer personligt; resten stemmer på partierne. Og de forventes derfor ikke nødvendigvis at have et personligt forhold til deres folketingsmedlemmer.

Tabel 2 viser, at partilederne er markant mere fremtrædende på Facebook. De mest populære er oppositionens politikere med Helle Thorning-Schmidt og Villy Søvndal som topscorere med henholdsvis knap 90.000 og 74.000 fans. Dernæst kommer statsminister Lars Løkke Rasmussen med knap 50.000 fans, mens det falder derefter.

Tabel 2 viser også, hvor mange fans partilederne har sammenholdt med partiets valgresultat ved folketingsvalget i 2007. Her er Enhedslistens Johanne SchmidtNielsen den markante topscorer med over 21 pct., mens Villy Søvndal (16 pct.) og Helle Thorning-Schmidt (10 pct.) indtager de andre pladser på podiet. Det er kun en lille del af vælgerne, der er fans af partilederne i de fleste partier.

Det samlede antal danske partimedlemmer er for nedadgående, men det skyldes primært et fald for de tre store, gamle partier, Venstre, Socialdemokraterne og
Konservative, da de andre partier i de sidste ti år har oplevet medlemsfremgang (Kosiara-Pedersen 2010). Sammenholdes antallet af fans af partiledernes Facebook sider med antallet af partimedlemmer i deres partier, viser Tabel $2 \mathrm{i}$ sidste spalte, at der i hovedparten af partierne (ikke Venstre, Konservative og Liberal Alliance) er flere fans end medlemmer. Dette indikerer, at en del partier har en gruppe af støtter, der er parate til at offentligt at erklære deres tilhørsforhold, og som enten foretrækker dette mere uforpligtende tilhørsforhold, eller som bare aldrig lige har fået meldt sig ind.

Opgørelsen af folketingsmedlemmernes tilstedeværelse på Facebook viser, at en tredjedel slet ikke er på Facebook. Af dem der er, har de fleste en personlig profil med begrænset antal venner. Kun en fjerdedel har en side egnet til politisk kommunikation. Partiledere nyder den største popularitet på deres sider. Partilederne har i flere partier flere fans, end partiet har medlemmer, men langt færre fans, end partiet har stemmer. Flere partier opfordrer medlemmer og støtter til at blive venner med dem på Facebook - og det er der trods alt en del, der har gjort. Men overordnet set er relationship marketing gennem Facebook ikke en solidt forankret strategi i partierne.

\section{Partiledernes og vælgernes aktivitet på Facebook}

Én ting er, at partierne og partilederne er på Facebook. Noget andet er, om de er der, fordi det er nyt og et 'must'; om de anvender Facebook til traditionel en-vejs-kommunikation eller til at skabe nye interaktive former for relationer med vælgerne.

Tabel 3 viser, hvor aktive partilederne er på Facebook i løbet af en måned. Johanne Schmidt-Nielsen er langt den mest aktive med næsten to wall-posts per dag. Den overvejende del af partilederne sender dog ca. én wallpost hver eller hver anden dag. Anders Samuelsen er den mindst aktive.

På trods af de større fanskarer er de to statsministerkandidater næstmindst aktive. Det kan på den ene

Tabel 2. Antal fans på partiledernes Facebook sider, december 2010.

\begin{tabular}{|l|c|c|c|}
\hline Partileder & Antal fans & Fans/ vælgere 2007 (pct.) & Fans/ medlemmer 2010 (pct.) \\
\hline Helle Thorning-Schmidt (S) & 89.258 & 10.1 & 186 \\
\hline Villy Søvndal (SF) & 73.951 & 16.4 & 448 \\
\hline Lars Løkke Rasmussen (V) & 46.442 & 5.1 & 90 \\
\hline Johanne Schmidt-Nielsen (EL) & 15.823 & 21.1 & 343 \\
\hline Pia Kjærsgaard (DF) & 13.128 & 2.7 & 129 \\
\hline Margrethe Vestager (RV) & 9.853 & 5.6 & 141 \\
\hline Lene Espersen (KF) & 9.663 & 2.7 & 62 \\
\hline Anders Samuelsen (LA) & 1.795 & $(1.8)$ & 39 \\
\hline
\end{tabular}

Note: Tredje søjle viser antal fans ift. antal stemmer ved folketingsvalget 2007. Antal stemmer til Ny Alliance er anvendt for Anders Samuelsen, selvom Ny og Liberal Alliance langt fra er identiske. Data om antal medlemmer er indsamlet fra partierne i foråret 2010. Data om antal fans er indsamlet 10.-12. december 2010. 
Tabel 3. Partiledernes poster, kommentarer og likes, absolut og ift. antal fans

\begin{tabular}{|l|c|c|c|c|c|c|}
\hline Partileder & Post & Fans/post & Kommentarer/post & Fans/ kommentarer & Likes/ Post & Fans/ likes \\
\hline Johanne Schmidt-Nielsen (EL) & 57 & 278 & 51 & 5,4 & 244 & 1,1 \\
\hline Margrethe Vestager (RV) & 38 & 259 & 35 & 7,4 & 152 & 1,7 \\
\hline Lene Espersen (KF) & 35 & 276 & 8 & 34,5 & 37 & 7,5 \\
\hline Pia Kjærsgaard (DF) & 21 & 625 & 71 & 8,8 & 111 & 5,6 \\
\hline Villy Søvndal (SF) & 21 & 3521 & 221 & 20,7 & 511 & 6,9 \\
\hline Lars Løkke Rasmussen (M) & 17 & 2732 & 132 & 40,4 & 1036 & 7,8 \\
\hline Helle Thorning-Schmidt (S) & 11 & 8114 & 208 & 24,9 & 67 & 6,7 \\
\hline Anders Samuelsen (LA) & 4 & 449 & 18 & & & 67 \\
\hline
\end{tabular}

Note: Data er indsamlet i november 2010.

side give anledning til at konkludere, at antallet af fans i højere grad afspejler partiets generelle popularitet end partiledernes aktivitet og indsats for at vedligeholde relationer til vælgerne via Facebook. På den anden side kan Helle Thorning-Schmidts 11 opdateringer på en måned være tilstrækkeligt til at opretholde kontakt til vælgerne og give en følelse af en kontinuerlig relation.

Antallet af kommentarer til wall-posts giver et overordnet billede af vælgernes lyst til at engagere sig. Et blik på partiledernes vægge viser, at der er meget stor forskel på aktiviteten. Tabel 3 viser, at der på Helles ThorningSchmidts side er 208 kommentarer pr. wall-post, hun selv har lagt ud, mens tallet for Villy Søvndal er 221. For Lene Espersens vedkommende er der kun i gennemsnit 8 brugere, der responderer på hendes wall-posts.

Sammenholdes antallet af kommentarer med antallet af fans, viser det sig, at Johanne Schmidt-Nielsen og Margrethe Vestager, skarpt forfulgt af Pia Kjærsgaard, er bedst til at mobilisere deres fans. Helle ThorningSchmidt og Lene Espersen mobiliserer færrest andele fans.

Mens antallet af kommentarer tegner et billede af det generelle aktivitet og engagement blandt fans, giver antal „likes“ et fingerpraj om, hvor stor grad af ideologisk homogenitet eller enighed, der er på siden. At „like“ el- ler „synes godt om“ indikerer netop, at man er enig i og bakker op om budskabet.

Igen er Helle Thorning-Schmidt topscorer med hele 1036 likes pr. wall-post. Også Villy Søvndal er med 511 likes pr. wall-post godt med. Det samme er Johanne Schmidt-Nielsen. Sammenholdes antal likes med antal fans kan partilederne grupperes i tre, hvor Johanne Schmidt-Nielsen og Margrethe Vestager får flest pr. fan, mens Lars Løkke Rasmussen får færrest. Resten ligger midt i mellem, hvor ca. hver 7. fan vælger at 'like' en wall-post fra partilederen.

Tabel 4 viser, at billedet af en aktiv debatkultur går igen, når man kigger på fansenes egne posteringer. Lars Løkke Rasmussens havde ikke mange wall-posts selv, men hans side vidner om et aldeles stærkt fællesskab med hele 87 wall-posts fra forskellige fans, der tilmed bliver responderet på af andre brugere. På Helle ThorningSchmidts side er der endnu flere wall-posts fra andre 111 , men der er omvendt ikke så stor interesse for at fortsætte debatten.

Sammenholdes antallet af wall-posts med antallet af fans, er Pia Kjærsgaards fans de mest aktive, dernæst kommer Margrethe Vestagers og Johanne SchmidtNielsens fans. De mindst aktive er Lene Espersens fans.

Mest interessant i denne forbindelse er imidlertid, at Anders Samuelsen og Villy Søvndal har afskåret deres

Tabel 4. Antal wall-posts fra fans, samt kommentarer og likes pr. wall-posts

\begin{tabular}{|l|c|c|c|c|}
\hline Partileder & Posts fra fans & Fans/ post & Kommentarer/ post & Likes/ post \\
\hline Helle Thorning-Schmidt (S) & 111 & 804 & 2,7 & 0,9 \\
\hline Lars Løkke Rasmussen (N) & 87 & 533 & 15 & 2 \\
\hline Pia Kjærsgaard (DF) & 54 & 243 & 8 & 2,4 \\
\hline Johanne Schmidt-Nielsen (EL) & 34 & 465 & 0,7 & 0,2 \\
\hline Margrethe Vestager (RV) & 25 & 394 & 2,4 & 1 \\
\hline Lene Espersen (KF) & 3 & 3221 & 1 & 1 \\
\hline Villy Søvndal (SF) & Ikke muligt & - & - & - \\
\hline Anders Samuelsen (LA) & Ikke muligt & - & - & - \\
\hline
\end{tabular}

Note: Data er indsamlet i perioden 29. november - 5. december 2010. 
Tabel 5. Partiledernes svar til egne og andres wall-posts, antal svar (antal posts)

\begin{tabular}{|l|c|c|}
\hline Partileder & Svar til egne posts (posts i alt) & Svar til fans' posts (posts i alt) \\
\hline Johanne Schmidt-Nielsen (EL) & $57(57)$ & $0(34)$ \\
\hline Lars Løkke Rasmussen (M) & $11(17)$ & $0(54)$ \\
\hline Pia Kjærsgaard (DF) & $4(21)$ & $21(25)$ \\
\hline Margrethe Vestager (RV) & $4(38)$ & $0(3)$ \\
\hline Lene Espersen (KF) & $0(35)$ & $0(111)$ \\
\hline Helle Thorning-Schmidt (S) & $0(11)$ & |kke muligt \\
\hline Villy Søvndal (SF) & $0(21)$ & |kke muligt \\
\hline Anders Samuelsen (LA) & $0(4)$ & \\
\hline
\end{tabular}

Note: Data er indsamlet i perioden 29. november - 5. december 2010.

fans muligheden for selv at skrive indlæg. For tilhængere af de to partiledere er det kun muligt at svare på ledernes indlæg, mens der ikke er mulighed for selv at bringe emner på banen. Det er dermed et aktivt fravalg af brugerstyret debat, en grundsten i relationship marketing.

Et andet - og måske endnu mere centralt - udtryk for partiledernes vilje til at indgå $\mathrm{i}$ en reel dialog og langsigtet interaktion med brugerne på siden er, hvorvidt partilederne giver feedback på kommentarerne. Tabel 5 viser, at her står det imidlertid ganske sløjt til. Johanne SchmidtNielsen er den eneste partileder, der konsekvent svarer på alle kommentarer - kritiske kommentarer, opklarende spørgsmål osv. 57 gange har hun deltaget i debatter, som er igangsat af hendes egne wall-posts og 9 gange har hun svaret på spørgsmål i wall-posts, der er initieret af fansene. I så godt som alle tilfælde med personlig adressat til spørgeren. Margrethe Vestager udmærker sig desuden ved konsekvent at svare på stort set alle wall-posts, der er skrevet af fans - også her med personlig adressat.

Lars Løkke Rasmussen har i 11 tilfælde svaret på spørgsmål, der er udsprunget af hans egne statusopdateringer, men ikke en eneste gang taget dialogen op, når diskussionen er startet af en bruger. Ser man desuden nærmere på karakteren af hans svar er de sjældent stilet mod enkeltpersoner, men har mere general oplysende karakter. Det samme er tilfældet for Pia Kjærsgaards fire svar.

Generelt må man konstatere, at feedbacken og den reelle respons fra partilederne på deres brugeres engagement er yderst begrænset. Det er kun Enhedslistens Johanne Schmidt-Nielsen og Radikales Margrethe Vestager, der reelt bruger Facebook til interaktion - og dermed i overensstemmelse med tankegangen i relationship marketing.

Langt de fleste sider bærer omvendt præg af envejskommunikation, hvor fansene stort set er overladt til sig selv. Forudsætningen for, at man kan tale om en reel dialog, er netop, at partilederen (eller ansatte i deres navn) også giver feedback på de reaktioner, der kommer i kølvandet på deres egne wall-posts. Hvis ikke dette er tilfældet, er det vanskeligt at tale om en reel anvendelse af relationship marketing. Dette tyder på, at en del partiledere primært forsøger at opretholde relationen til deres Facebook fans ved at give mere eller mindre eksklusiv information.

Tabel 6 viser karakteren af politikernes wall-posts. Politikerne kan søge et mere aktivt forhold til vælgerne ved at opmuntre, spørge og opfordre vælgerne til aktivt at forholde sig til en given problemstilling - dialogbaserede indlæg. „Tag med mig til demonstrationen i morgen“, lød to stort set enslydende beskeder fra de to mest inter-

Tabel 6. Karakteren af partiledernes indlæg, pct. (antal)

\begin{tabular}{|l|c|c|c|c|}
\hline Partileder & Andel politiske (antal) & Andel personlige (antal) & Andel dialogbaserede (antal) & Antal poster i alt \\
\hline Johanne Schmidt-Nielsen (EL) & $84(48)$ & $4(2)$ & $12(7)$ & 57 \\
\hline Margrethe Vestager (RV) & $68(26)$ & $11(4)$ & $21(8)$ & 38 \\
\hline Lene Espersen (KF) & $97(34)$ & $3(1)$ & $19(4)$ & 35 \\
\hline Pia Kjærsgaard (DF) & $67(14)$ & $14(3)$ & $5(1)$ & 21 \\
\hline Villy Søvndal (SF) & $86(18)$ & $10(2)$ & $6(1)$ & 21 \\
\hline Lars Løkke Rasmussen (N) & $88(15)$ & $6(1)$ & $9(1)$ & 17 \\
\hline Helle Thorning-Schmidt (S) & $82(9)$ & $9(1)$ & $0(0)$ & 11 \\
\hline Anders Samuelsen (LA) & $100(4)$ & $0(0)$ & & 4 \\
\hline
\end{tabular}

Note: Data er indsamlet i november 2010. 
aktionssøgende partiledere på Facebook, Johanne Schmidt-Nielsen og Margrethe Vestager, da demonstrationen „Kærlighed uden grænser“ $1 ø b$ af stablen som reaktion på regeringens plan for et pointsystem for udlændinge. Derudover er det dog kun Pia Kjærsgaard, der med fire dialogbaserede indlæg har samme direkte tilgang i dialogen med vælgerne. Langt de fleste politikere holder sig til det politiske, selv om tabel 5 allerede har vist, at der kun blandt halvdelen af partilederne på Facebook søges en fortsat dialog om det politiske indhold.

Facebook er en naturlig platform til at give vælgerne et mere personligt billede, lade dem komme tættere på, og på den måde skabe en mere personlig relation til vælgerne. Resultaterne af analysen viser dog, at relationen er overvejende professionel. Det er kun i begrænset omfang, at partilederne deler ud af personlige træk, som da Johanne Schmidt-Nielsen uploader en sang hun kan lide fra youtube, og Margrethe Vestager ønsker en kollega tillykke med fødselsdagen.

Resultaterne viser sammenholdt med tabel 3 og 4, at Johanne Schmidt-Nielsen, Margrethe Vestager og Pia Kjærsgaard ikke kun er de mest dialogsøgende, men at de også har flest kommentarer og likes (sammenholdt med antal fans). Det tyder på, at partilederne selv kan bidrage til, at Facebook bliver et redskab til politisk debat.

\section{Konklusion}

I hvilket omfang bruger danske partier og partiledere Facebook til at skabe nye relationer til vælgerne gennem relationship marketing? Bruger partierne Facebook - hvis ja, hvilken karakter har interaktionen mellem vælgere og partiledere på Facebook?

Danske folketingsmedlemmer anvender Facebook, men anvendelsen forekommer mere personligt end politisk motiveret. Kun en fjerdedel af folketingsmedlemmerne har en side velegnet til kommunikation med vælgerne. Partilederne har alle sider, men deres aktivitetsniveau varierer meget.

Der finder ganske vist en høj grad af interaktion sted på siderne, men mobiliseringen og den brede aktivitet sker primært blandt partiledernes venner og fans. Det er snarere undtagelsen end reglen, at partilederne selv deltager i dialogen og dermed aktivt dyrker relationen til de digitale kontakter. Når partierne opfordrer vælgerne til at 'følge dem på Facebook' - så er det korrekt formuleret; det handler om at høre på partilederen, det er ikke en ny anledning til dialog.

Men analysen viser også, at partilederne kan bidrage til at skabe politisk dialog, hvis de selv ønsker det. De mest dialogsøgende partiledere har flere kommentarer til deres egne indlæg og får oftere nye indlæg fra deres fans. Selvom det er Helle Thorning-Schmidt og Villy Søvndal, der ubetinget har flest Facebook fans, er det Johanne Schmidt-Nielsen, Margrethe Vestager og Pia Kjærsgaard, der bedst formår at udnytte Facebooks potentiale til at skabe nye relationer til vælgerne.

Selvom der er nogle partiledere, der gør nogle gode forsøg, udnytter de danske partier ikke Facebooks fulde potentiale til at skabe nye relationer til vælgerne.

Det betyder dog, for det første, ikke at Facebook ikke er et nyttigt værktøj for partierne. Selvom relationship marketing ikke er implementeret fuldt ud, er det en ny relation, der tilbydes støtter og medlemmer. Denne relation kan give dem et stærkere tilhørsforhold til partiet og partilederen og dermed lyst til at engagere sig i andre partipolitiske aktiviteter og til at promovere partiets politik for deres omgangskreds. Specielt ift. støtter er det en ny mulighed for til en vis grad at formalisere støtte-rollen.

Det betyder for det andet heller ikke nødvendigvis, at partierne slet ikke er interesseret i principperne for relationship marketing. Selvom Facebook er den mest oplagte digitale platform, er den digital, hvormed den stiller særlige krav. Partierne kan nemlig også implementere aspekter af relationship marketing på anden vis, f.eks. ved at få støtter og medlemmer til at give faste bidrag til partiet, kvartalsvis kontingentbetaling og registrering af potentielle valgkampagneaktivister direkte hos lokale kampagneansvarlige (jf. Kosiara-Pedersen 2011).

For det tredje er den trods alt begrænsede brug af Facebook i en tilfældig periode ikke nødvendigvis karakteristisk for partiernes brug af Facebook i en valgkamp. Selvom relationship marketing lægger op til, at relationer til vælgerne skabes og genskabes løbende og netop ikke kun i de perioder, hvor kampagnerne er intensive, er det muligt, at partierne prioriterer anderledes i selve valgkampen. En valgkamp øger den politiske opmærksomhed, hvormed flere vælgere bliver nysgerrige og måske nysgerrige nok til at gå på partilederens Facebook side for at få et indblik i, hvem partiet og partilederen er.

Et essentielt tilbagestående spørgsmål er, om ovenstående billede af partiernes anvendelse af relationship marketing via Facebook i 'fredstid' også gælder ved valg; partiernes primære jagtsæson på vælgere. Partierne når potentielt andre vælgersegmenter med en Facebook side end med en helsides annonce på s. 3 i Berlingske. Antallet af avislæsere er dalet, og det er ikke herigennem partierne får fat på især de yngre generationer af vælgere. Facebook er blot en af flere muligheder for partierne; en mulighed, der som vist af nogle partiledere kan virke, og som over tid kan udvikle nye forhold mellem partier og vælgere. Vil partierne bruge det i en valgkamp? 


\section{Litteratur}

Bannon, D (2005), „Relationship Marketing and the political process“, Journal of Political Marketing, Vol. 4, No. 2/3, pp. 73-90.

Dermody, J \& R Scullion (2000), „Delusions of Grandeur? Marketing's Contribution to 'Meaningful' Western Political Consumption“, European Journal of Marketing, Vol. 35, No. 9/10, pp. 1085-1098.

Facebook (2010) Www.checkFacebook.com lokaliseret 16.12.2010.

Grönroos, C (1994), „From marketing mix to relationship marketing, Towards a paradigm shift in marketing“, Management decision, Vol. 32 , pp. 4-20.

Henneberg, S (2002), „Understanding Political Marketing“, i N O'Shaughnessy \& S Henneberg (red.), The Idea of Political Marketing, Praeger, Westport, pp. 93-142.

Henneberg, S \& N O’Shaugnessy (2009), „Political Relationship Marketing: Some macro/micro thoughts“, Journal of Marketing Management, Vol. 25, No. 1-2, pp. 5-29.

Jackson, N (2006), „Political parties, Their E-Newsletters and Subsribers: One Night Stands or a Mirriage made in Heaven?", i J Davies \& B Newman (red.): Winning elections with Political Marketing, The Haworth Press, New York, pp. 149-175.

Keller, KL (2001), „Building customer-based brand equity“, Marketing Management, July-August, pp. 15-19.

Klastrup, L (2008), „Brugen af 'sociale medier' online i valgkampen 2007“, i Foreningen af Danske Internetmedier (2008), Internettets rolle under Folketingsvalget 2007. Foreningen af Danske Internetmedier, København.

Kosiara-Pedersen, K (2010), Partiernes medlemstal 2010. CVAP Aktuel Graf. Center for Valg og Partier, Institut for Statskundskab, Kø- benhavns Universitet. http://www.cvap.polsci.ku.dk/publikationer/ aktuel_graf/aktuel_graf_6/

Kosiara-Pedersen, K (2011), „Forandres partimedlemskab af partiernes brug af politisk marketing?", i SW Nielsen (red.) Politisk Marketing. Under udgivelse.

Kotler, P (1972), „A Generic Concept of Marketing“, Journal of Marketing, Vol. 36, April, pp. 46-54.

Kotler, P \& SJ Levy (1969), „Broadening the Concept of Marketing“, Journal of Marketing, Vol. 33, Jan., pp. 10-15.

Lees-Marshment, J (2001a), Political Marketing and British Political Parties, Manchester University Press, Manchester.

Lees-Marshment, J (2001b), „The Marriage of Politics and Marketing“, Political Studies, Vol. 49, pp. 692-713.

Lloyd, J (2005), „Square Peg, Round Hole? Can Marketing-Based Concepts Such as the 'Product' and the 'Marketing Mix' Have a Useful Role in the Political Arena?", Journal of Nonprofit \& Public Sector Marketing, Vol. 1, No. 1, pp. 27-46.

Norris, P (2001), Digital Divide: Civic Engagement, Information Poverty and the Internet worldwide. Cambridge University Press, New York.

Pedersen, Karina \& Tim Knudsen (2005), „Denmark: Presidentialization in a Consensual Democracy“, i T Poguntke \& P Webb (red.) The Presidentialization of Politics. A Comparative Study of Modern Democracies, Oxford University Press, Oxford.

Scarrow, SE (1996), Parties and their Members. Organizing for Victory in Britain and Germany. Oxford University Press, Oxford.

Strömbäck, J (2007), „Political marketing and Professionalized Campaigning: A conceptual analysis“, Journal of Political Marketing. Vol. 6, No. 2-3, pp. 49-67. 